THE JOURNAL

or

\title{
THE ROYAL ASIATIC SOCIETY.
}


THE

\title{
JOURNAL
}

OF THE

\section{ROYAL ASIATIC SOCIETY}

or

\author{
GREAT BRITAIN AND IRELAND.
}

\section{F0R THE FIRST HALF-YEAR OF $190 \%$.}

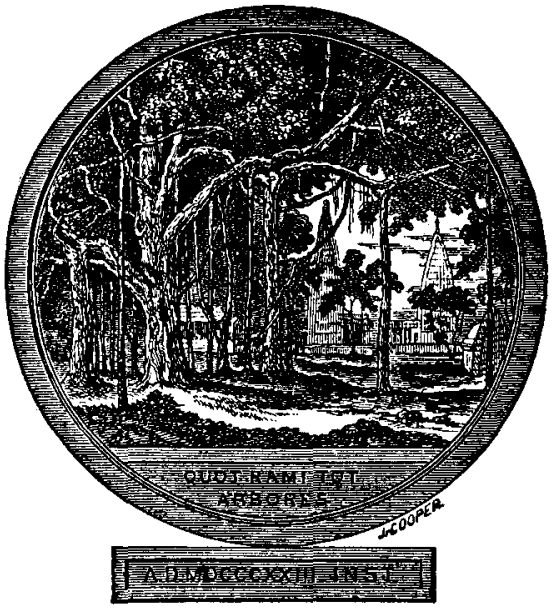

PUBLISIIED BY THE SOCIETY,

22, ALBEMARLE STREET, LONDON, W.

MDCCCCVII. 
STEPHEN AUSTIN AND SONE,

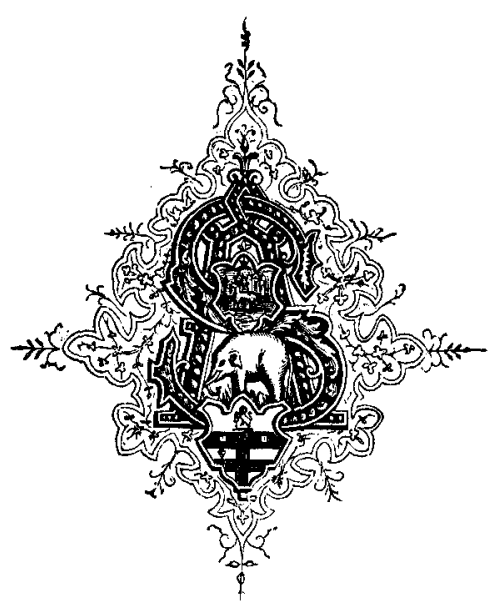

PRINTARS, HERTFORD. 


\section{CONTENTS}

\section{FOR THE FIRST HALF-YEAR OF 1907.}

\section{ARTICLES.}

I.-Studies in Ancient Indian Medicine. II. On some obscure Anatomical Terms. By A. F. Rudolf HoERNLE $\ldots \ldots \ldots \ldots \ldots \ldots \ldots \ldots$

II.-An Unidentified MS. by Ibn al-Jauzi, in the Library of the British Museum, Add. 7,320. By H. F. Amedroz $\ldots \ldots \ldots \ldots \ldots \ldots \ldots \ldots \ldots \ldots$

III.-The Five Rivers of the Buddhists. By W. Hoer, D.Lit., I.C.S. (retd.) ..................

IV.-The Foundation of Fustât and the Khitțahs of that

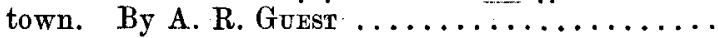

V.-The Pahlavi Texts of Yasna XXII, for the first time critically translated. By Professor Lawrence Mills

VI.-White Hun (Ephthalite) Coins from the Panjāb. By

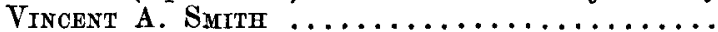

VII.-The Oldest Record of the Rämāyana in a Chinese Buddhist Writing. By K. Watanabe .........

VIII.-The Inscription on the Piprahwa Vase. By J. F. FleEt, I.C.S. (retd.), Ph.D., C.I.E. ...........

IX.-Further Notes on the Bābar-nāma MSS.: The Elphinstone Codex. By Annftte S. Beveridge ..

X.-The Tablet in Cuneiform Script from Yuzghat. By Theophilus G. Pincees, M.R.A.S. ............

XI.-A Chinese Text corresponding to Part of the Bower Manuscript. By K. Watanabe ..............

XII.-Contributions to the Biography of 'Abd al-Kădir of Jìlān. By D. S. Margoliovth $\ldots . . \ldots \ldots \ldots .267$

XIII.-Modern Hinduism and its Debt to the Nestorians. By George A. Grierson, C.I.E., Ph.D., D.Litt. .. 311

XIV.-Phallus-Worship in the Mahābhārata. By B. C.

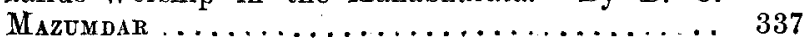

XV.-The Tradition about the Corporeal Relics of Buddha. By J. F. Fleet, I.C.S. (retd.), Ph.D., C.I.E. .... 341

XVI.-Some Seals from Kasia. . By J. Рн. VogeL, Ph.D. .. 365 XVII.-The Chronicles of Pegu : a text in the Mon language. By C. 0 . Blagden $\ldots \ldots \ldots \ldots \ldots \ldots \ldots \ldots . . . \ldots \ldots$ 
XVIII.-MSS. Cecil Bendall. Edited by LouIs DE LA VaLLÉ Poussin ...................... 375

XIX.-The Kachin Tribes and Dialects. By O. Harson .. 381 XX.-Panegyric on Sulțān Jaqmaq, by Ibn 'Arabshāh .... 395

\section{MISCELLANEOUS COMMUNICATIONS.}

The Lokesvara Image of Čandi Jago. By J. Рн. VogrL .... 161

The Mint-Town Shahr-i-Nau. By H. Beveridge $\ldots \ldots \ldots 161$

The Destruction of Native Libraries. By C. E. LdaRd $\ldots . .162$

Arabic Inscriptions on Textiles. By R. Sewell ........ 163

The use of the Passive Gerund in Sanskrit. By A. Berriedale

KEITH

164

Vèthadipa. By G. A. Griersos $\ldots \ldots \ldots \ldots \ldots \ldots \ldots .166$

A Note on the Nasabu'l-Khirqa. By Reynold A. Nrcholson 166

Suggested emendation in the Gulistān, Story 17 of Book i.

By George RANKING $\ldots \ldots \ldots \ldots \ldots \ldots \ldots \ldots \ldots . \ldots \ldots$

Dr. Paul Brönnle .......................... 168

A Correction. By J. F. FLeET $\ldots \ldots \ldots \ldots \ldots \ldots \ldots \ldots .169$

The Early Use of the Era of B.c. 58. By J. F. Fueet $\quad \ldots . .169$

Itsing and Vāgbhața. By J. JoLLY $\ldots \ldots \ldots \ldots \ldots \ldots, 172$

Two Verses from Indian Inscriptions. By F. KreLtorn .. 175

There is no Modification in the Karma Doctrine. By the

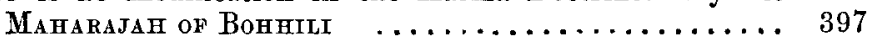

Archæology in South India. By Robert Sewell ....... 4r 1

Babor; Babbāpura. By J. Рн. Voged ............ 403

Who were the Kankas? By B. C. Mazumdar .......... 406

Denarius and the date of the Harivainśa. By B. C. MAZUMdaR 408

Rājaña, Rājanya. By G. A. Grienson ............. 409

Sàǹnhāyana Srauta Sūtra: Books XVII and XVIII. By

A. Berriedale Ketth ................... 410

Vyäghramuśa. By A. M. T. JaCkson $\ldots \ldots \ldots \ldots \ldots \ldots, 413$

Itsing and Văgbhața. By A. F. Rudolf Hokrnes ....... 413

Further Note on the Poem attributed to Al-Samau'al. By

H. Hinsch Feld ....................... 418

Śiva as Lakuliśa. By J. F. Fleet................. 419

The Origin of the Dēvanāgari Alphabet........... 426 


\section{NOTICES OF BOOKS.}

Arehaeological Survey of India: Annual Reports for 1902-3 and 1903-4. Reriewed by J. F. FLEET ...........

P. W. Sснмдт, S.V.D. Die Mon-Khmer-Völker. By G. A.

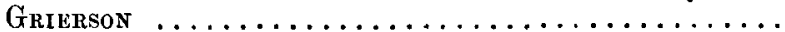

Cemlestrivo Schiaparelut. The Travels of Ibn Jubair. By H. Beveridge $\ldots \ldots \ldots \ldots \ldots \ldots \ldots \ldots \ldots \ldots$

E. Lunet de Lajonquière. Ethnographie du Tonkin

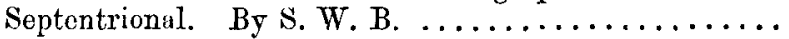

M. J. De Gozse. Descriptio Imperii Moslemici, by Al-

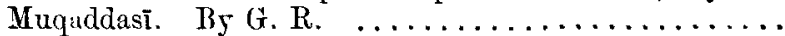

F. H. Weissbach. Die Inschriften Nebukadnezars II im Wâdi Brìsā und am Nahr el-Kelb. By 'T. G. Prnches. . Arthur Ungand, Dr.Phil. Babylonisch-A ssyrische Grammatik.

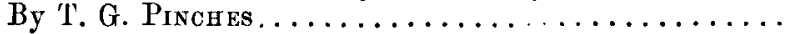

Stephen Langdon, Ph.D. Lectures on Babylonia and Palestine. By T. G. Prnches........................

Francors Thureau-Dangin. Les Inscriptions de Sumer et

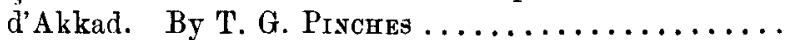

Albert T. Clay. Documents from the Temple Archives of

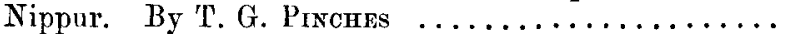

A. A. Bevan. The Naka'id of Jarìr and al-Farazdak. By C. J. L. ..............................

Gơindra Nítrr DUtr. The Brahmans and Kayasthas of

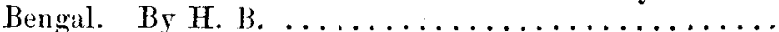

G. Rat. Al-Mostatraf. By A meer Alt ...........

R. GEYer. Zwei Gedichte von al-'A‘sā: (1) Mā Bukā'u. By F. Krenkow $\ldots \ldots \ldots \ldots \ldots \ldots \ldots \ldots$

Dr. J. Schentelowitz. Die Apokryphen des Rgveda. By

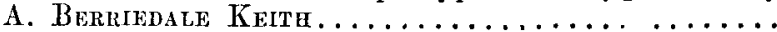

Dr. C. Snorck Huraronje. The Achehnese. (Translated from the Dutch by the late A. W. S. O'Sullivar.) By

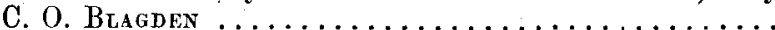

Sir R. C. Temple, Bart., C.I.E. (1) The Thirty-seven Nats. (2) A Native Account of the Thirty-seven Nats. By

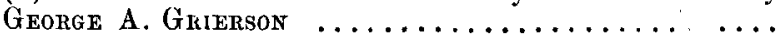

K. Volders. Katalog der islamischer, christlich-orientalischen, jüdischen, und samaritanischen Handschriften der Universitäts-Bibliothek zu Leipzig. By H. Hrasch Ferd.

Rev. F. A. Krein. The Religion of Islam. By D. S.

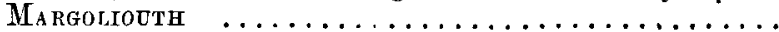

E. H. Whinfield and MīnZz̄ Mug̣amarad Kazvīnī. Lawā'ih : a treatise on Șüfism by . . . Jāmī. By E. G. B. 
H. KerN. Vaitulya, Vetulla, Vetulyaka. By Lours DE LA

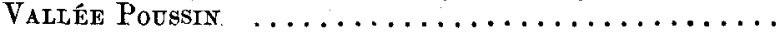

P. A. Trompson, A.M.I.C.E. Lotus Land, being an Account of the Country and the People of Southern Siam. By

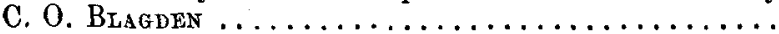

Stuphen W. Bushell, C.M.G. Chinese Arts. By R. K. D. 438

Wrluta Foster. The English Factories in India, 1618-1621. By Donald Ferguson .....................

Fuederick Victor Dickins, C.B. Primitive and Mediæval

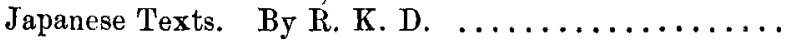

Mrs. Rhrs DAvids, M.A. Dukapatthana, being part of the Abhidhammapitaka: vol. i. By LoUrs DE LA VALLÉE

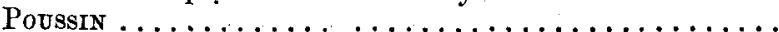

Charlas A. Sherring. Western Tibet and the British

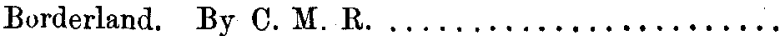
456

Edward G. Browne, M.A., M.B., F.B.A. A Literary History of Persia from Firdawsí to Sa'dí. By R. A. N. .....

Dr. P. Deussen. Vier Philosophische Texte des Mahâbhâratam. By A. Berrtedale Kerth ..............

Camillo Beccart, S.I. Notizia e Saggi di opere e documenti inediti riguardanti la Storia di Etiopia durante i secoli XVI, XVII, e XVIII. By D. S. Margoliouth ......

G. A. Grierson. The Piśāca Languages of North-Western

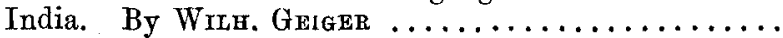

Lieut.-Col. Georas S. A. Ranking, M.D. An EnglishHindustani Dictionary. By W. HoEY.............

Vincent A. Suitr. Catalogue of the Coins in the Indian Museum, Calcutta: vol. i. By O. C.

\section{Notes of the Quakter.}

General Meetings of the Roral Asiatic Society ...... 245, 477

Discussion on Modern Hinduism and the Nestorians .. 477

Principal Contents of Oriental Journals ..........246, 504

Obituary Notices.

Major Henry George Raverty. By H. B.

Adpitions to the Library

Lrst OF Mímbers.

Titule-page and Contents for the Fitest Half-year. 


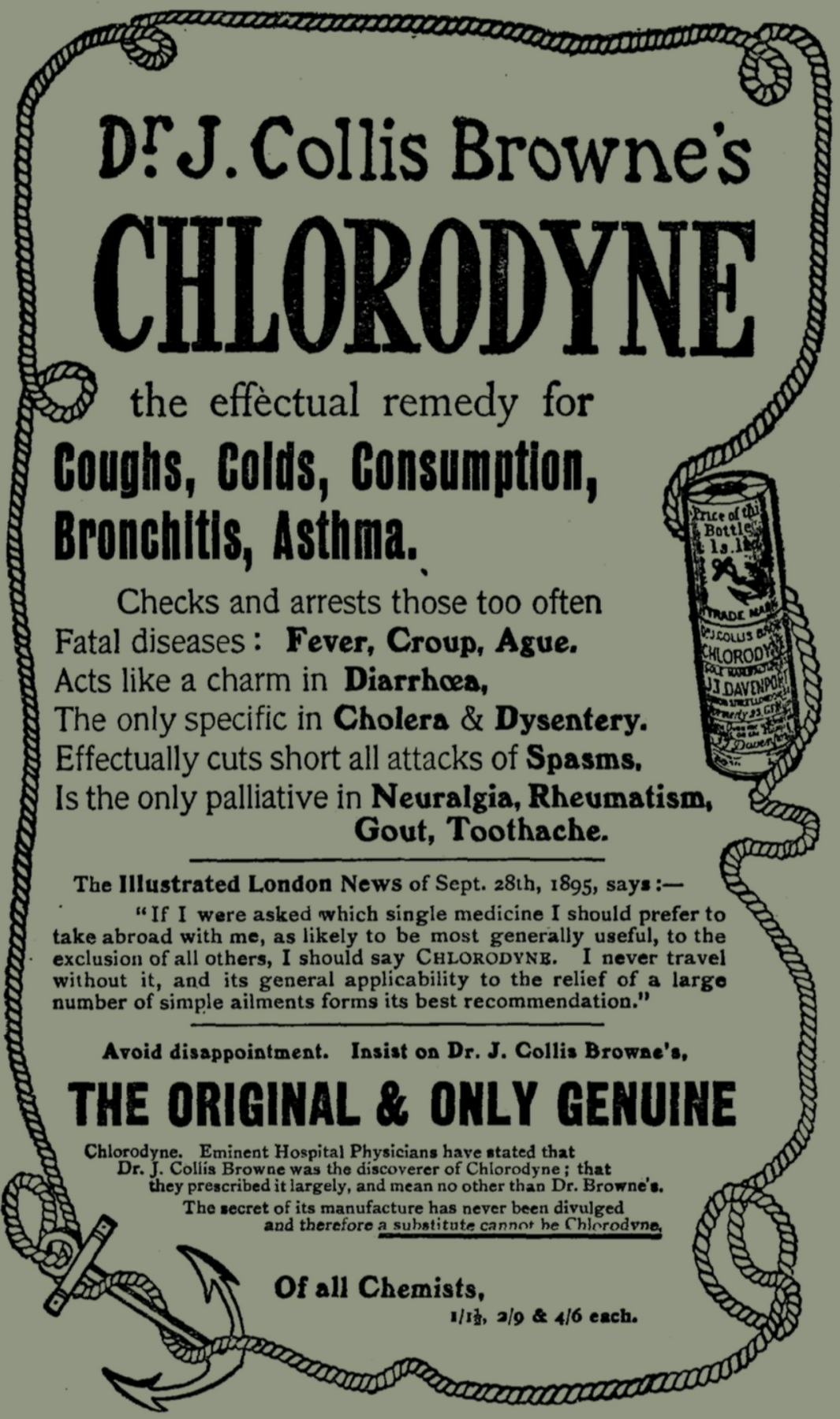




\section{ROYAL ASIATIC SOCIETY \\ or \\ GREAT BRITAIN \& IRELAND. \\ 22, Albemarle Street, Piccadilly, $W$. \\ Special Mrotice.}

THE ROYAL ASIATIC SOCIETY publishes Quarterly an Illustrated Journal, containing Original Articles on the Languages, the Archæology, the History, the Beliefs, or the Customs of the East.

A Special Article in the Journal gives each Quarter an account, as complete as possible up to date, of all scholarly work being done throughout the world in these branches of inquiry.

The Annual Subscription to the Society is THREE GUINEAS a Year for Resident, and THIRTY SHILLINGS a Year for Non-Resident, Members.

\section{Compositions.}

Members may compound for their subscriptions at the following rates:Resident Members for life $\quad \ldots \quad \ldots \quad \ldots \quad \ldots \quad \ldots \quad 45$ guineas

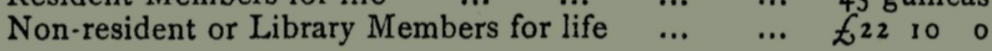

Each Member who has paid his Subscription for the current year receives the Journal post free, has the use of the Library at the Society's rooms, and admission to the meetings of the Society. Throeguinea snbscribers may also borrow books.

Libraries and Non'-Members may obtain the Journal postfree by a Subscription of Thirty Shillings a year if paid in advance direct to the Secretary. The Price of each Part separately is Twelve Shillings. 